\title{
DO NORMS MATTER? A CROSS-COUNTRY EVALUATION
}

\author{
JOHN C. COFFEE, JR. ${ }^{\dagger}$
}

\section{INTRODUCTION}

That corporate behavior may be more shaped and determined by social norms than by legal rules seems to be an idea whose time has come. 'Respected academics have placed the relative efficacy of social norms as compared with legal rules at the center of the debate over the judicial role in corporate law, and some have suggested that there are areas of internal corporate behavior and decisionmaking that courts should monitor less rigorously because social norms adequately govern behavior."

Although the relevance of norms cannot be denied, the problem with this debate is that it has an ineffable and subjective character. Of course, individuals internalize norms, seek to maximize their reputational capital, and function in teams that operate based on informal systems of consensus and cooperation. They do so within both corporations and all other forms of social organization. But once this is said, can any testable propositions be framed? In particular, can a corporation's perceived compliance with norms that are not legally enforced be shown to affect the market value of its securities?

† Adolf A. Berle Professor of Law, Columbia University Law School

${ }^{\prime}$ Set Robert Cooter \& Melvin A. Eisenberg, Faimess, Character, and Efficiency in Firms, 149 U. PA. L. REV. 1717 (2001) (arguing that firm-specific faimess norms promote efficiency, especially when supported by reputation effects); Melvin A. Eisenberg, Corporate Law and Social Norms, 99 ColuM. L. Rev. 1253 (1999) (discussing the role of social norms in several key areas of corporate law, including fiduciary duties, corporate governance, and takeorers); Edward B. Rock \& Michael L. Wachter, Islands of Conscious Power: Law, Norms, and the Self-Governing Corporation, 149 U. PA. L. REV. 1619 (2001) (arguing that corporate law is a sophisticated mechanism for facilitating self-governance by nonlegally enforceable rules and standards); Donald Langevoort, The Human Nature of Corporate Boards: Law, Norms and the Unintended Consrquences of Independence and Accountability (Sept. 8, 2000), http:/ / papers.ssm.com/sol3/papers.cfm?cfid=221773\&:cftoken=19218905\&abstract_id $=241402$.

"Sir, $\epsilon$.g., Rock \& Wachter, supra note 1. But see Paul Mahoney \& Chris Sanchirico, Competing Norms and Social Evolution: Is the Fittest Norm Efficient?, 149 U. PA. L. REv. 2027, 2045-46 (2001) (arguing that the corporate norm that evolves within the organization may not necessarily be efficient). 
This brief Article will answer both that compliance with nonlegally enforceable social norms can significantly affect market value and that innovative legal engineering designed to develop credible signals of such compliance may be one of the most important services that corporate attorneys can perform for their clients. In particular, existing research has shown that (1) it is feasible to measure the private benefits of control that those holding voting control over the corporation are likely to extract from minority shareholders, and (2) a credible signal that a controlling shareholder will cease or reduce the expropriation of such private benefits appears to produce a significant increase in the corporation's stock price. The unresolved question is what constitutes a credible signal.

This Article starts with the recognition that the average private benefits of control vary significantly across countries. But why? The simplest explanation ascribes this variation to differences in law between jurisdictions: for example, the law of jurisdiction $X$ could privilege controlling shareholders by allowing them to extract benefits from their corporation in the form of above-market salaries or nonpro-rata payments in connection with self-dealing transactions. But, this explanation cannot fit all cases. To illustrate, if the substantive law is essentially similar between two jurisdictions while the private benefits of control appear to be significantly different, then some other explanation must be found. One possible alternative explanation could involve differences in enforcement mechanisms: one jurisdiction might have established powerful and well-incentivized mechanisms of private enforcement, while another jurisdiction having the same substantive law did not. Or, one jurisdiction might invest more heavily than the other in public enforcement. Still, if these explanations also fail (or, at least, seem implausible), then the next most logical explanation involves social norms. That is, if two jurisdictions having similar legal rules and enforcement systems appear to permit controlling shareholders to extract on average very different levels of private benefits, then we may be witnessing a difference in prevailing norms. This Article will argue that this pattern is not only possible, but pervasive.

Part I of this Article will offer evidence that suggests that the social norms regarding the behavior of controlling shareholders do differand differ significantly-across jurisdictions. Even within jurisdictions having relatively similar legal rules, the level of compliance with these norms appears, on average, to differ materially. Although some of this variation no doubt can be explained in terms of differences in 
enforcement risks, it will be argued that the magnitude of these differences cannot be explained plausibly on any such deterrencerelated basis.

Part II will turn to possible explanations for the magnitude of these differences in the private benefits of control across jurisdictions. It will take the uncharacteristic step (for a corporate law article) of seeking to relate these differences to other social characteristics that distinguish the jurisdictions being compared-in particular, to the levels of law compliance and crime within the jurisdiction. Although no satisfactory metric exists for measuring law compliance across jurisdictions, some reasonable proxies do suggest a rough correspondence: namely, societies with high crime and/or low social cohesion are also characterized by high private benefits of control.

Part III will then turn to the potential for value creation through credible signaling that a corporation will comply with social norms that are not legally enforced. On the one hand, this Article will suggest that there are incentives for a race to the top: that is, corporations that do bond themselves to protect the interests of minority shareholders beyond the level that is mandated legally or is enforced in their home jurisdiction, and that credibly signal this intent, can enhance significantly their share prices. Such creative legal engineering can more than pay for itself because some evidence already suggests that corporations in countries with weak legal systems can more than double their stock price through such self-help measures."

On the other hand, there is also a reverse side to this coin: if controlling shareholders in "amoral" jurisdictions that are characterized by high private benefits of control were to acquire control of corporations incorporated in "moral" jurisdictions characterized by low private benefits of control (but in which the expropriation of private benefits was not legally constrained), a movement in the reverse direction toward greater inefficiency could begin. If controlling shareholders in "amoral" jurisdictions are not deterred by internalized norms or by the threat of reputational loss then they would have every logical incentive to acquire control in order to extract greater private benefits than had the preceding controlling shareholder in the "moral" jurisdiction. Once, such perversely motivated takeovers would have been infeasible because of the high national barriers to transnational takeovers. Today, however,

Ser infra notes 49-51 and accompanying text. 
in capital markets that are increasingly globalized and in which corporate control is increasingly contestable, movements in both directions seem both possible and plausible.

\section{SOCIAL NORMS AND THE PRIVATE BENEFITS OF CONTROL: A CROSS-COUNTRY COMPARISON}

An important new body of research has argued that legal rules protecting the rights of investors-and minority shareholders in particular-are essential to the development of deep and liquid securities markets. ${ }^{4}$ In a provocative series of articles, Professors Rafael La Porta, Florencio Lopez-de-Silanes, Andrei Shleifer, and Robert Vishny (hereinafter "LLS\&V") have documented the existence of significant differences among countries in terms of the breadth and liquidity of their capital markets, the ownership concentration of publicly traded firms, the dividend policies of firms, and the access of firms in these markets to external capital-differences that correlate closely with the nature of each country's legal system. More to the point, they have found that common law countries seem to outperform civil law countries by a significant margin in terms of both the depth and liquidity of their capital markets and the degree of dispersion in share ownership. Why? LLS\&V conclude that the superior quality of the legal protections afforded minority shareholders in common law jurisdictions principally explains these differences. ${ }^{5}$

Yet, although LLS\&V have unquestionably shown a statistically significant correlation between strong capital markets and certain specific legal protections that tend to characterize common law legal systems, correlation does not prove causation. The confounding

4 See, e.g., RAFAel La PORTA ET AL., INVEstor Protection aNd CoRPorate VALUATION (Nat'l Bureau of Econ. Research, Working Paper No. 7403, 1999) (finding evidence of higher valuation of firms in countries with better protection of minority shareholders); Rafael La Porta et al., Agency Problems and Dividend Policies Around the World, 55 J. FIN. 1 (2000) (supporting the outcome agency model of dividends); Rafael La Porta et al., Corporate Ownership Around the World, 54 J. FIN. 471 (1999) (finding that in a sample of twenty-seven wealthy economies' corporations, relatively few firms are widely held); Rafael La Porta et al., Law and Finance, 106 J. POL. ECON. 1113 (1998) [hereinafter La Porta et al., Law and Finance]; Rafael La Porta et al., Legal Determinants of External Finance, 52 J. FIN. 1131 (1997) (demonstrating that countries with poorer investor protections as measured by the character of legal rules and the quality of law enforcement have narrower capital markets).

${ }^{5}$ For the most recent statement of their position, see Rafael La Porta et al., Investor Protection and Corporate Governance (n.d.), http://papers.ssrn.com/sol3/papers.cfmitcfid $=221923 \&$ cftoken $=76970454 \&$ abstract_id $=183908$. 
problem of multicollinearity thus makes its customary appearance here, as it often does when attempts are made to determine the true independent variable that influences the dependent variable. ${ }^{\circ}$ Of the various nagging doubts surrounding their research, perhaps the most perplexing is the possibility that the specific legal protections identified by LLS\&V are really proxies for some deeper, but hidden, characteristic of common law legal systems.

The point here is not to reject their "law matters" thesis, which would be highly plausible even in the absence of strong statistical correlations between minority legal protections and ownership dispersion. Rather, it is to suggest that the line between law and norms may be harder to define than this body of research has yet recognized. Specifically, investors may invest in public corporations in common law legal regimes (and may not invest in similar corporations in civil law legal regimes) less because they believe they have enforceable legal rights that adequately constrain managers and controlling shareholders than because they believe managers and controlling shareholders in these common law legal regimes will abide by a series of legally nonenforceable norms. These norms (and the related corporate governance practices that implement them) may as a practical matter restrict unfair self-dealing and otherwise limit the potential for expropriation of the minority shareholder's investment. In short, investors invest because they expect to be treated "fairly" in a common law legal system (and have been treated so in the past), and they refrain from making similar investments in a civil law regime (or they make them only at severely discounted prices) because they have the opposite expectations (and possibly the opposite experience in the past).

Although the specific norms and governance practices that facilitate investment could have a close association with statutory legal protections that are more prevalent in common law legal systems, norms and legal rules can be entirely independent of each other, even though they appear closely associated. For example, no statute or legal rule in the United States or the United Kingdom requires a

"Multicollinearity refers to the possibility that covariation among independent rariables can give the misleading impression that a measured independent variable has caltied a change in a dependent variable when in fact the causation is attributable to a hidden linkage between the dependent variable and a "true" independent variable that is corariant with the "false" independent variable. See MICHAEL O. FINkELSTEIN \& BKLCE LEVIN, STITISTICS FOR LAWIERS 350-52 (1990) (explaining the statistical ignificance of the regression coefficients). Suffice it to say here that this is a common problem in many' regression studies and seldom can it be wholly corrected. 
majority of the board of directors to be independent of management, but this is in fact the widely prevailing practice in the case of public corporations in both countries. Such a practice also might be statistically associated (or "co-variant") with a legal rule (such as the legal rules governing proxies in the United States, which do facilitate shareholder ability to elect or oust the board of directors), but this correlation still does not imply causation. Hence, even if a norm or governance practice is associated with certain legal rules, this correlation can be misleading if it is assumed that the legal rules "cause" the board to be independent. Indeed, this would be a clear example of multicollinearity at work, creating the misimpression that specific legal rules (here, the proxy rules) had a causal relationship with the depth and liquidity of the U.S. capital markets.

Reality is, however, still more complex than this example would indicate because legal rules may sometimes be embedded in a matrix of norms and conventional practices that all interact with and reinforce each other. Arguably, corporation statutes can specify a "standard of conduct" for corporate fiduciaries that is higher than the standard that courts will actually use in imposing liability. A relevant example is supplied by the "safe harbor" or "sanitizing" statutes that most U.S. states have enacted in order to deal with the problem of conflict of interest transactions between a corporation and its director. ${ }^{8}$ As interpreted by most courts, these statutes give considerable deference to the decision of independent directors to approve a self-dealing transaction between the corporation and a director, and they relax the standard of judicial review that would prevail otherwise..$^{9}$ Although these statutes may recommend a high standard of conduct, they do not require compliance in order for the defendant to avoid liability. Indeed, they do not require an independent board, and they even permit directors who have not made full disclosure to the board to validate the conflict of interest transaction by proving its intrinsic fairness. ${ }^{10}$ The impact of these "safe

${ }^{7}$ See Melvin Aron Eisenberg, The Divergence of Standards of Conduct and Standard's of Review in Corporate Law, 62 FORDHAM L. REV. 437 (1993).

${ }^{8}$ Examples of such "safe harbor" or "sanitizing" statutes are supplied by N.Y. BUS. CORP. LAW $\$ 713$ (McKinney Supp. 2001) or DEL. CODE ANN. tit. 8, \$144 (1991).

${ }^{9}$ Cases differ on how much protection such disinterested approval by independent directors affords. Compare Marciano v. Nakash, 535 A.2d 400 (Del. 1987) (stating that disinterested approval triggers the business judgment rule), with Fliegler v. Lawrence, 361 A.2d 218 (Del. 1976) (stating that approval merely removes the "cloud" caused by the director's self-interest).

${ }^{10}$ See, e.g., DEL. CODE ANN. tit. 8, $\$ 144(a)(3)$ (stating that a contract or 
harbor" statutes is rather to create an incentive for corporations to adopt an independent board in order that its managers will receive relative immunity from judicial review. To this extent, even if the statutes mandate nothing, they reinforce the normative convention (and probably the market's expectation) that public corporations should have independent boards.

Legal rules and social norms thus have a way of melting into each other without a sharp, clear line defining where the law ends and the norms begin. Investors realize that they are protected by both, and hence an unexplained departure from a prevailing governance practice might elicit a market penalty. Yet, at least within the U.S. context, attempts to identify corporate governance practices that actually enhance shareholder value and elicit a positive market reaction generally have been unsuccessful." Possibly, shareholders understand that there can be justifications for departures from generally accepted governance practices; or possibly, they recognize that a variety of overlapping functional substitutes for any individual corporate governance practice exists so that an isolated departure may have little meaning.

If research within the United States on the relationship between corporate governance practices and market valuation has not been fruitful, it does not follow that this same pattern will persist outside the United States or that the relationship is necessarily weak. The first thing one learns when one looks outside the United States is that there are enormous variations, depending on the corporation's jurisdiction of incorporation, in the market's expectation that minority shareholders will face expropriation. Such expropriation most typically occurs because of the ability of a controlling shareholder to extract what economists term the "private benefits of control" from the corporation. ${ }^{12}$ The term "private benefits of control" is a shorthand expression for all of the ways in which those in control of a corporation can siphon off benefits to themselves that are

tran action is valid without disclosure to the board if it is "fair as to the corporation as of the time" authorized or approved); N.Y. BuS. CORP. LAW $\$ 713$ (b) (placing the duty on the director in such cases to prove the transaction was "fair and reasonable to the corporation at the time").

"Professor Black assesses these studies in his article in this volume. Bernard Black, Dor's Corporate Governance Matter? A Crude Test Using Russian Data, 149 U. PA. L. REV. 2131, 2133-34 \& nn.2-6 (2001).

${ }^{12}$ For a discussion of this standard term, see Lucian Arye Bebchuk \& Marcel Kahan, A Framework for Analyzing Legal Policy Towards Proxy Contests, 78 CAL. L. REv. $1073,1090(1990)$. 
not shared pro rata with the other shareholders, including through (1) above-market salaries, (2) unfair self-dealing transactions with the corporation, (3) insider trading, or (4) the issuance of shares to themselves at dilutive prices. ${ }^{13}$ In all jurisdictions, corporate law attempts to address and limit the extraction of private benefits of control, but with varying degrees of success.

The new focus on comparative corporate governance has led researchers to seek to measure variations in the private benefits of control across countries. Tatiana Nenova, a Harvard economist, directly approached this task by identifying a sample of all dual-class firms whose securities were listed in the thirty largest national capital markets in the world. ${ }^{14}$ Overall, she found some 661 firms. Dual-class firms are corporations with two classes of shares having different voting rights, and thus they permit direct observation of the value of voting control. Essentially, once adjustments are made for any differences in cash flow or dividend rights, the aggregate premium at which the higher-voting class trades over the lesser-voting class is assumed to represent the value of control. ${ }^{15}$ The bottom-line conclusion from this study was that the value of corporate control differed enormously across countries, and in certain countries-most notably, Brazil, Chile, France, Italy, Mexico, and South Koreaamounted to "alarmingly high" levels that were between a quarter and a half of the firm's market capitalization. ${ }^{16}$ The extreme case was Mexico, where controlling shareholders were found to "expropriate one half of the value of the company, sharing the remaining half with minority shareholders in proportion to share holdings." ${ }^{17}$ Yet, in other countries, including the United States and Canada, the value of control was much less (generally below four percent), ${ }^{18}$ thus

${ }^{13} I d$.

${ }^{14}$ Tatiana Nenova, The Value of Corporate Votes and Control Benefits: A CrossCountry Analysis 3 (Sept. 21, 2000), http://papers.ssrn.com/sol3/papers.cfm?cfid= 2216348 \&ftoken=7463198\&abstract_id=237809.

${ }_{15}$ The basic methodology used in this study is not new and parallels that earlier used by Luigi Zingales in a series of seminal articles. Luigi Zingales, The Value of the Voting Right: A Study of the Milan Stock Exchange Experience, 7 REV. FIN. STUD. 125 (1994); Luigi Zingales, What Determines the Value of Comporate Votes?, 110 Q.J. ECON. 1047 (1995).

${ }_{16}$ Nenova, supra note 14 , at 4.

17 Id. The use of the word "expropriate" here is conclusory and possibly unjustified because one does not know what the minority shareholders paid for their shares. If minority shareholders assumed that one-half of the firm's cash flow would be diverted to controlling shareholders, they presumably paid correspondingly less for their shares.

Is Id. 
apparently indicating that the private benefits of control diverted to controlling shareholders in these countries were considerably less.

Perhaps more importantly, not only did the private benefits of control differ dramatically across countries, but the average private benefits of control differed systematically in terms of the "legal families" to which individual countries belonged. Table 1 sets forth these differences: $:^{19}$

Table 1

Legal Family

\section{Scandinavian Civil Law Countries}

Common Law Countries

German Civil Law Countries

French Givil Law Countries
Average Private Benefits of Control as a Percentage of a Firm's Market Capitalization

At first glance, this data certainly seems to support the "law matters" hypothesis." One can read the data as demonstrating that the tougher the legal environment, the less the private benefits that the control holder can extract. Indeed, Professor Nenova concluded that: "More than $70 \%$ of systematic differences in vote value are explained by the quality of investor protection that non-controlling shareholders enjoy as per the country laws, their rights in the case of control transfer, and the extent of law enforcement."

But is it this simple? Clearly, forces of social control seem more at

"Id. The sample contained a substantial number of observations of firms for each legal family: Scandinavian civil law countries (109), common law countries (161), French cixil law countries (224), and German civil law countries (167). Id. at 30-31.

* The "law matters" hypothesis essentially posits that economic development, particularly in transitional economies, depends upon the protection and enforcement of minority shareholder rights. See, e.g., John C. Coffee, Jr., The Future as History: The Prusifuts for Glabal Convergence in Copporate Governance and Its Implications, 93 Nw. U. L. REV. 641, 643-48 (1999). Obviously, the strongest proponents of this thesis have been LISXV. Sre supra note 4. Their claim that the common law outperforms the civil law in protecting minority shareholder rights is actually a subset, or a more specialized application of the broader "law matters" hypothesis.

Nenova, supra note 14 , at 4. 
work in some jurisdictions than others, and controlling shareholders in French civil law countries appear to feel substantially less inhibited than controlling shareholders elsewhere about extracting private benefits of control. But are those controlling shareholders less constrained because they are less deterred or because they can rationalize their behavior under social norms that view the controlling shareholder as more entitled to extract such benefits? In short, the data raises, but does not resolve, the critical issue of the relative role of law versus other forces of social control.

One way to approach this question is to ask whether significant differences in the average level of private benefits of control extracted by controlling shareholders can be explained plausibly by differences in the prevailing substantive law. That is, if the substantive law were highly similar but the average private benefits differed dramatically, it would become more difficult to explain these differences in terms of the relative efficacy of the substantive law. To the extent that prior research has generally focused on common law versus civil law countries, these studies plausibly have sought to attribute differences in outcome to the seemingly major differences between the common law and the civil law. But the foregoing data set is not so easily explained, and actually tends to subvert this explanation. As Table 1 above showed, Scandinavian legal systems seem to outperform both common law and French and German civil law legal systems in terms of reducing the private benefits of control. If common law legal systems are thus straddled on both sides by different forms of civil law systems, it becomes more difficult to rely on any explanation that assumes the natural superiority of the common law's technology for shareholder protection over that of the civil law.

In addition, significant variations are evident even within the same legal family. Table 2 breaks out some of the differences within family groups: $^{22}$

${ }^{22}$ Id. at 51 tbl.5 (measuring "[c]omparison of mean total vote value as a share of firm value, raw averages"). 
Table 2

\section{Country}

Scandinavian Countries

Denmark

Finland

Norway

Sweden

Common Law Countries

Australia

Canada

Hong Kong

South Africa

United Kingdom

United States

German Civil Law Countries

Germany

South Korea

Switzerland

French Civil Law Countries
Total Vote Value as a Share of Firm Value
0.008
$-0.05$
0.058
0.01

0.23

0.03

$-0.029$

0.07

0.096

0.02

0.095

0.29

0.05

0.23

0.23

0.28

0.29

0.36

Within common law countries, Australia stands out as an outlier. Although the United States, the United Kingdom, and Canada, each sharing much legal tradition and cultural heritage with Australia, all have low and closely similar percentages for total vote value as a percentage of firm value, Australia's percentage is over ten times higher than that of the United states and roughly two and one-half times the next highest common law country on this table..$^{23}$ Germany also requires special attention for the opposite reason. Although researchers have regularly criticized German civil law for its lack of minority protections, the German and British figures for total vote value as a percentage of firm value are almost identical: 0.095 and 0.096 , respectively. ${ }^{24}$ Yet, in the case of South Korea, which derived its

${ }^{23}$ It is possible that this could be a consequence of the limited number of observations (three) in this study of Australian firms. Id.

${ }^{* *}$ Here, there were numerous observations: sixty-five in the case of Germany and 
law from Germany but obviously not its cultural heritage or social norms, the corresponding percentage is 0.29 - or over three times as high. $^{2.5}$ The obvious inference is that "transplanted" law may not "take," possibly because it conflicts with the host country's own norms and customs. ${ }^{26}$

A closer examination of the foregoing table also suggests that the assumed superiority of common law to civil law represents a gross oversimplification. If one looks at the German and Swiss figures (and drops South Korea from the class of German countries as an example of the "transplant effect" ${ }^{\text {"2z }}$ ), then the value of control appears relatively similar in the case of both German and common law countries-despite significant differences in their legal regimes. In addition, Scandinavian countries do significantly better on average than common law countries in restricting the private benefits of control-again despite the presumed inferiority of the civil law tradition.

The real surprise that emerges from this table is the inferior performance of the French civil law countries. Uniformly, they exhibit very high values associated with voting control. Only South Korea and Australia rival their levels. Of course, it is this substandard performance of French civil law that fuels the LLS\&V hypothesis that the common law better protects minority shareholder rights than the civil law. But there is another possible interpretation. The French civil law countries in the foregoing table are culturally heterogeneous (Brazil and Chile do not derive their cultural standards or norms from France), whereas the common law countries in the foregoing table share greater cultural affinity and all at least historically experienced

twenty-seven in the case of the United Kingdom Id.

${ }^{25}$ There were sixty-five observations of South Korea firms and of German firms, so this comparison cannot be the result of one or two idiosyncratic firms. Id.

${ }^{26}$ One recent study does find that the way law is initially transplanted and received is a more important determinant of its legal effectiveness than the source of the law in terms of the legal family (for example, English, French, or Scandinavian) to which it belongs. See Daniel Berkowitz et al., Economic Development, Legality and the Transplant Effect (Nov. 1999), http://papers.ssrn.com/sol3/papers.cfm?cfid=221385\&:cftoken= 99302065\&abstract_id=183269. Studying the acceptance of new legal principles in forty-nine countries, they find that "transplanted law" succeeds when it is consistent with local customs or had a population that was already familiar with its basic legal principles. They estimate that, when these circumstances are not present, "transplanted law" will be, on average, one-third less effective. Id. Restated in this Article's terminology, this is essentially a finding that legal rules work best when they reinforce and are supported by the prevailing norms of the society.

${ }^{27}$ See id. (describing cultural incongruence as a principal reason why transplanted legal rules are not effective). 
British colonization and administration. This difference implies that the "transplant effect" could be surreptitiously at work here and could explain much of the disparity. That is, the attempted transplant of French civil law might not have taken because of its lack of congruence with local norms and customs, whereas the common law transplant did take because it was accompanied by British colonists who respected and accepted it.

This latter interpretation does not reject the "law matters" hypothesis that effective legal rules are essential to economic development. Rather, its more modest claim would be that in the wake of the failure of "transplanted" law, controlling shareholders were left with few constraints on their behavior and, by default, a de facto "take-the-money-and-run" ethic prevails. Put differently, although the applicable norms in South Korea, Mexico, and Brazil could differ significantly in their normative content, they may share the common characteristic of imposing little constraint on controlling persons." If so, however varied and nuanced these normative systems may be, they can be described as "weak" in an operational sense.

To sum up, a survey of all listed firms in some thirty countries shows that, in terms of limiting the private benefits of control, Scandinavian firms outperform common law country firms, which in turn outperform firms in German civil law countries-but all of these basically marginal differences pale in comparison to the virtual right to plunder that controlling shareholders seem to have in firms in French cisil law countries.

What interpretation best explains these results? LLS\&V's now standard explanation that the common law better protects minority shareholders cannot easily explain the Scandinavian superiority or the near equivalence between common law firms and German civil law firms. But the contrary hypothesis that "law does not matter" similarly fails to explain either the fact that deep and liquid securities markets are found only in common law countries or the dramatic failure of French civil law in constraining the private benefits of control.

To be able to account for these results, any theory that assigns primary causal responsibility to law would have to explain why the civil

This explanation still does not adequately account for high private benefits of control in France and Italy, which cannot be described as jurisdictions to which French cixil law has been "transplanted." Hence, these examples do support the LLS\&V lnpothesis.

-' For the fullest statement of this finding, see La Porta et al., Law and Finance, suparate 4 . 
law could outperform the common law in some countries but then underperform it in others. Such an explanation would logically have to respond either that (1) the civil law in Scandinavian countries was substantively very different from that in French or German countries (with French civil law being conspicuously more deficient), or (2) there were significant differences in the enforcement of legal rules that distinguished these three legal families. Neither explanation seems remotely plausible. First, Scandinavian civil law does not treat the corporation notably differently than do the civil laws of France or Germany. According to LLS\&V, who have constructed an "antidirector rights index" to measure the strength of the legal protections accorded shareholders, Scandinavian civil law ranks behind the common law and just equal to the world average. Scandinavian law also affords no special legal protections to "oppressed minority" shareholders." The one respect in which Scandinavia does seem to outscore its rivals is in ratings for the "Efficiency of the Judicial System" and freedom from "Corruption." Yet, high ratings for lack of corruption arguably evidence more the strength of norms within the country than the substantive superiority of its doctrinal law.

Second, in terms of enforcement capacity, the legal systems of Europe (both common law and civil law) differ markedly from that of the United States. Only the United States has the class action and the contingent fee, and these have been combined in the United States to assure generous compensation to the successful plaintiff's attorney in a class action. ${ }^{33}$ Finally, unlike the United Kingdom, the United States normally makes each side bear its own legal expenses, with the result that plaintiffs are spared the prospect of fee shifting against them of the typically greater legal expenses incurred by corporate defendants. Together, these three elements-the class action, the

${ }^{30}$ See La Porta et al., supra note 5, at 38 tbl.1. Scandinavia's "antidirector rights index" rating of 3 is behind the 4 rating given to common law countries and equal to the 3 rating specified as the "World Average," but ahead of the 2.33 rating given to both French civil law and German civil law countries. Id.

${ }^{31}$ Id. In contrast, $50 \%$ of German civil law countries and $94 \%$ of common law countries have such a remedy. $I d$.

${ }^{32}$ Even on these scores, German civil law countries were not far behind, although French civil law countries lagged badly. Id.

${ }^{33}$ Canada and a few other countries have begun to experiment with the class action, but do not reward class counsel with a contingent fee in the form of a presumptive percentage of the recovery. Hence, few class actions have yet been brought in these jurisdictions. 
contingent fee, and the American rule on fee shifting-have created in the United States (but basically nowhere else to any equivalent degree) an entrepreneurial system of private law enforcement. ${ }^{3.4}$ As a result, for a European legal system to compare favorably with the United States in terms of enforcement, it would have to compensate for weak private enforcement with very strong public enforcement of corporate legal rules. Again, this seems unlikely, because the SEC is generally recognized as the world's premier public enforcer in the area of corporate and securities law, and it has served as the template which several European countries have explicitly sought to emulate. Not only do the Scandinavian countries lack any comparable public enforcer, but their largest companies typically list on foreign stock exchanges (whether in New York, London, Paris, or Frankfurt), and hence are more subject to the self-regulatory rules of these bodies.

Where does this leave us? It suggests that if corporate law is reasonably similar across Europe and if aggregate enforcement efforts-both public and private-fall well below those in the United States, one must look beyond law to social norms to explain the very different performance of firms in Scandinavian, German, French, and common law countries.

\section{BEYOND LAW: WHAT ELSE EXPLAINS DIFFERENCES IN CORPORATE BEHAVIOR?}

To this point, we have examined only differences in substantive law and in legal enforcement in order to explain the significant differences in the magnitude of the private benefits of control that controlling shareholders extract across different jurisdictions. In a world in which all actors are assumed to be amoral and to be deterred only by the prospect of sanctions, this might exhaust the possible explanations. But an alternative set of explanations emerges if we postulate that the principal actors in corporate governance may internalize norms and act in accordance with them.

But is this proposition testable? Easy as it is to postulate norm internalization, it is more problematic to measure it or to relate it to cross-country differences in observed outcomes. Some approximate measures do, however, suggest themselves. For example, one can postulate that a strong norm of law compliance exists in some countries, but is less present or even absent in others. A rough proxy

"John C. Coffee, Jr., The Regulation of Entrepreneurial Litigation: Balancing Faimess and Efficingy in the Large Class Action, 54 U. CHI. L. REv. 877 (1987). 
for this norm might be the national crime rate. In this light, it is noteworthy that Scandinavian countries have long had crime rates well below that of most industrialized nations. ${ }^{35}$ A correspondence might then be hypothesized between a low crime rate and low expropriation of private benefits of control. If we look only to the Scandinavian countries, this generalization seems to work. Although there are few comparative studies of crime rates, a 1990 study under the auspices of the World Health Organization ranked twenty leading industrial countries based on victim survey data. ${ }^{36}$ Three Scandinavian countries were included: Finland, Norway, and Sweden. Norway ranked next to last (or 19th) with the second lowest rate of victimization and Finland and Sweden were ranked below average at 11 th and 13th, respectively, in terms of victimization rates. ${ }^{37}$

But if the premise that Scandinavians are more law-abiding than citizens of most other countries looks persuasive, it fails to provide an adequate explanation for corporate opportunism, because many countries with poor records on corporate governance did equally well in terms of crime rates. For example, the two German law countries in this same sample-Germany and Switzerland-ranked 15th and 17th, respectively. ${ }^{38}$ Even France, the alleged symbol of shameless opportunism in corporate law matters, ranked 14th, better than either Sweden or Finland. What countries had the highest levels of crime victimization? The United States came 1st, New Zealand 2nd, Australia 3rd, and Canada 4th. ${ }^{39}$ Obviously, the common law countries do not do well on this scorecard, even though they perform excellently in terms of policing the private benefits of control. Yet, the relationship between crime rates and corporate opportunism is not generally inverse, as the Scandinavian success testifies.

Of course, one explanation for this seeming paradox may be that serious crime (at least, the types measured by crime victimization studies) and corporate opportunism are different phenomena, engaged in by different classes of persons, located typically in

${ }^{35}$ This has consistently been true for decades. See, e.g., HENRY MILNER, SWEDEN: SOClal DEMOCRACY IN PRACTICE 206 (1989) (discussing Sweden's rates of drug use, prostitution, crime, and delinquency).

${ }^{36}$ See Franklin E. Zniring \& Gordon Hawkins, Crime Is Not the ProbleM: LETHAL VIOLENCE IN AMERICA 7-8 (1997) (discussing Jan van Dijk and Pat Mayhew's 1992 study of victim surney crime rate categories and homicide rates in twenty countries).

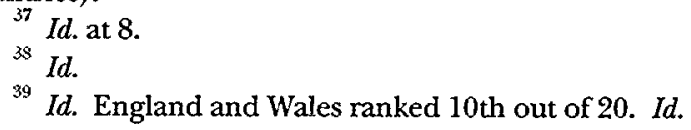


different positions within society. Violent crime is, let us assume, engaged in most commonly by the social underclass, while controlling shareholders who expropriate wealth from minority shareholders belong, by definition, to a more socially privileged class. In Scandinavia, however, both groups seem to obey the law more than elsewhere."

Scandinavia's unique position actually suggests a revised hypothesis. Perhaps what is most distinctive about Scandinavia is its level of social cohesion and homogeneity. In contrast, the United States is characterized by much greater diversity, both ethnic and religious, and possibly by a greater degree of polarization between social groups. Arguably, social cohesion produces greater conformity with social norms. Not only can this revised hypothesis explain low exploitation of minority shareholders in Scandinavia, but it may also explain the high expropriation rates in many French civil law countries. Table 2 above showed that Mexico was characterized by the highest expected level of expropriation, because it had the highest value accorded to voting control (36\%); Brazil and Chile were not far behind at $23 \%$ each. Although nominally French civil law countries, in reality each are Hispanic nations with sharp class and racial divisions, significant political tensions, and (in the case of Brazil and Chile) a recent history of military governments. None of this enhances social cohesion. Indeed, Brazil and Mexico are two of the very few countries that have a higher homicide rate than the United States." Similarly, Russia is characterized by both a very high homicide rate and a unique level of expropriation of minority

"I" One is thus led to consider more speculative theories. Perhaps Scandinavians have seen too many Ingmar Bergman movies and are too guilt-ridden as a result to engage in any form of misconduct. Alternatively, there is the "blondes have more fun" theory under which Scandinavians ignore money to pursue goals that Freud understood.

"Although the United States is often loosely asserted to have the highest homicide rate in the world, the evidence is otherwise. According to the Statistical Abstraft of the United States, the U.S. homicide rate in 1997 was 7.0 per 100,000 citizens (a level well above all European countries other than Russia), which was a decline from the 7.9 level in 1996. See Bureau OF CENSUS, U.S. DeP'T OF COMMERCE, STATISTICAL ABSTRICT OF THE UNITED STATES 217 (119th ed. 1999). Brazil, in contrast, has a rising homicide rate that reached 25 per 100,000 in 1996 (more than three times the U.S. rate in that year). Paulo Sergio Pinheiro, Democratic Governance, Violence and the (Un)Rule of Law, 129 DAEDALUS 119, 122-23 (2000). In 1992, the Mexican homicide rate was estimated at 16.8 per 100,000 citizens. Richard J. Cottrol, Submission Is Not the Answer: Lethal Violence, Microcultures of Criminal Violence and the Right to Self-Defense, $69 \mathrm{U}$. COLO. L. REV. 1029, 1036 n.16 (1998). 
shareholders. ${ }^{42}$

Social cohesion must also be viewed through the prism of history. The recent history of a jurisdiction may demonstrate that its social fabric has been disrupted in a manner that could affect its corporate governance. For example, corporate governance in Russia may be weak not only because of problems within its corporate and judicial systems, but because the prior system of social organization (that is, the communist bureaucratic state) collapsed, and political instability has largely reigned in its wake. Simple as this point sounds, it applies well beyond the Russian context or even that of other transitional economies with evident internal political tensions (for example, Mexico, Brazil, or Chile). To illustrate, the United States was once clearly subject to very high private benefits of control during the late ninteenth century. This was the era of the robber barons, and stock was regularly watered, the securities market manipulated, and corporate control exploited to promote the personal interests of the controlling shareholder. ${ }^{43}$ Not coincidentally, this was also the era immediately following the Civil War, when long simmering internal tensions had erupted and caused a total breakdown of the former constitutional system. Moreover, the post-Civil War era in the United States was also a time of rapid and dislocating social and economic change, as a new class of industrialists (such as Rockefeller, Carnegie, and Vanderbilt) arose to replace the business leaders of the prior era who had been drawn primarily from merchant and professional groups. The business tactics of this era also changed as the new industrialists (most notably, Rockefeller) sought monopoly status and forced their competitors into submission. In such a predatory environment and at a time well before the emergence of a professional managerial class at the turn of the twentieth century,"

${ }_{42}$ In 1993 , the Russian homicide rate was estimated at 19.5 per 100,000 citizens, which is midway between the homicide rates of Brazil and Mexico, and two and onehalf times the current U.S. rate. Cottrol, supra note 41 , at 1036 n.16.

${ }^{43}$ For a concise history of corporate law and governance during the era, see LAWRENCE FRIEDMAN, A HISTORY OF AMERICAN LAW 511-25 (2d ed. 1985). I have elsewhere analyzed at length the measures taken by both investment bankers and regulators to curb the opportunistic behavior of the robber barons during the late nineteenth century. See John C. Coffee, Jr., The Rise of Dispersed Ownership: What Causes the Separation of Ownership and Control?, 111 YALE L.J. I (2001).

${ }^{44}$ Alfred Chandler has devoted much of his career as a business historian to tracing the rise of a professional managerial class in the United States, which transition he essentially dates to the end of the nineteenth and the beginning of the twentieth centuries. See Alfred D. Chandler, JR., THE Vistble haND: THE MANAGerial, REVOLUTION IN AMERICAN BUSINESS (1977). 
there were few unifying or socializing forces that generated normative constraints on the business managers of that era. In this light, the corporate governance landscape of Russia in the late 1990s looked much like that of the United States during the 1870s.

The point here is that normative consensus emerges most clearly in a business society characterized by social cohesion. Elsewhere in this Symposium, Professors Lynn Stout and Margaret Blair argue that behavior within firms is governed by internalized norms and that the primary motor forces within the corporation are the "behavioral phenomena of internalized trust and trustworthiness." True as this may be, trust and trustworthiness are learned behaviors, to which the corporate actor is socialized in the broader society. The more that society as a whole is turbulent, chaotic, and divided and the more that it rewards predatory or opportunistic behavior, the more that such experiences may influence behavior within the corporation as well. To sum up, to the extent that a capacity for trust is the critical organizational glue (as they argue), its ability to restrain behavior and limit the private benefits of control may depend upon the level of social cohesion within the broader society.

This social cohesion thesis, however, does not answer all questions. For example, both France and Italy have moderate overall crime rates, but have high rates of expropriation of the private benefits of control that rival those of Brazil and Chile. While perhaps not as cohesive or homogeneous as Scandinavia, neither France nor Italy approaches Brazil or Mexico in terms of internal tensions, class divisions, or ethnic conflict. Despite this fact, their controlling shareholders appear to behave much like those in these more conflicted societies.

Thus, a final possibility that could explain high private benefits of control may be some characteristic of the average corporation in a civil law country that justifies (or, at least, can be used to rationalize) the belief of its controlling shareholders that they are entitled to extract greater private benefits. To illustrate this hypothesis, let us contrast the prototypical experience of two start-up companies, one in the United States and the other in a civil law jurisdiction. In the United States, the young entrepreneurs of a high-tech start-up company secure venture capital backing, and within four to five years effect a successful initial public offering ("IPO") in which the 
company goes public at a price-earning ratio of fifty to one. Public stockholders buy over $70 \%$ of the equity in this company, leaving management marginally in control with a $30 \%$ block (typically, the venture capitalists who initially financed the company cash in their chips and move on within a year of the offering). The founders' shares here do not carry a sizable control premium because control has in effect been sold to the public market (where a determined corporate bidder might well be able to acquire it in a hostile tender offer).

Next, let us focus on more standard European history. A company is founded, without the assistance of venture capital financing, which is less available in Europe, in part because venture capitalists cannot anticipate an early IPO in the wake of which they will be able to liquidate their investment. In fact, the company never effects an IPO in the United States/United Kingdom sense of that term, but over time (say, ten to twenty years) its stock becomes dispersed into the hands of customers, suppliers, and descendants of the founders, and trading begins in an illiquid market. Because its founders still hold an easily controlling block of stock in their company (say, 75\%), the publicly traded shares trade at a large discount that reflects that control premium held by the founders (and their ability to extract private benefits). Hence, some public shareholders, who are unaffiliated with the founders, may acquire blocks in the secondary market equal to $1 \%$ to $3 \%$ of the outstanding stock at highly discounted prices that are well below the company's liquidation value per share.

Will the managements of these two prototypical companies regard their public shareholders in the same light? Arguably, they will not. The American management sees a shareholder class that paid a high premium in the expectation that management owes them a fiduciary duty that demands exacting loyalty. In contrast, the European founders and managers may regard their public shareholders as opportunists, who bought at discounted prices that reflected the founders' right to control and to extract private benefits. Indeed, the European founders could even view their failure to extract their traditional level of private benefits from their company as, in effect, bestowing a windfall on the public shareholders who bought at discounted prices that assumed those private benefits would continue to be extracted.

To present this justification is not to accept it. There are social costs and allocative inefficiencies to a capital market system that 
systematically underprices the stock of such firms in concentrated ownership systems. Rather, the point of this illustration is, first, that norms are central, and, second, that they may be context specific. Arguably, the American entrepreneurs might have the same sense of entitlement to extract private benefits if they saw their minority shareholders buying their stock at heavily discounted prices. Hence, the operative norms may vary less because of national normative differences than because of differences in the characteristic development of firms, with "weak" European securities markets in effect producing correspondingly "weaker" social norms about the obligations of controlling shareholders. In turn, based on these "weaker" norms, "weaker" duties might be codified in civil law systems than in common law systems. There is a potential irony here. While L.L.S\& V argue that strong markets presuppose strong laws protecting minority shareholders, one can at least imagine the reverse dynamic: strong markets come first and create a demand for stronger laws to protect the constituency of investors who have entered those markets."

\section{NORIS AND THE MARKET}

Norms are often defined as informal rules of conduct that constrain self-interested behavior but are not enforced by any authoritative body that can impose a sanction. ${ }^{47}$ The absence of an enforcer does not mean, however, that there is no sanction. Reputational loss to a firm, when it violates a norm (and is detected in so doing), can be severe. ${ }^{18}$ What happens, however, when norm violation is endemic, in effect when "everyone is doing it?" In such a world, where the norm is more honored in the breach than in the observance, the market cannot logically expect that any firm will comply with the norm, and it should discount all firms by the value that the expected noncompliance subtracts from what otherwise

"I I have made the argument at length elsewhere, tracing the histories of the New Yink Stoch Exchange, the London Stock Exchange, the Paris Bourse, and the various Citman stock exchanges. Ste Coffee, sutra note 43.

"This detinition roughly parallels that used by Mahoney \& Sanchirico, supra note 2 , at 2030 ("Norms ... are rules of conduct that constrain self-interested behavior and th.t are adopted and enforced in an informal, decentralized setting.").

St' Jonathan M. Karpoff \& John R. Lott, Jr., The Reputational Penalty Firms Bear firm Crmmitting Ciminal Fraud, 36 J.L. \& ECON. 757, 784 (1993) ("[T]he loss incurred by a firm accused or found guilty of fraud is its lost reputation."). "[T] stock market value could be due to the reputational loss suffered by the firm." Id. 
would be the firm's market capitalization. Even in such a world in which the norm is arguably more nominal than real, however, those firms that can credibly signal their intent to comply with the norm may be able to enhance their market value.

Professor Bernard Black's article in this Symposium provides striking evidence that the market does respond to credible signals that a firm will comply with norms that protect minority shareholders-at least when such a signal differentiates the firm from the majority of firms that are not so complying. ${ }^{49}$ Essentially, he finds a strong and statistically significant correlation between the corporate governance ranking that a group of Russian firms received from one Russian investment bank and the ratio of their actual market capitalization to their potential market capitalization in a Western market, as independently estimated by another Russian investment banking firm. ${ }^{50}$ That is, some firms in his Russian sample traded at prices well under $1 \%$ of their potential Western market capitalization, while others traded at levels as high as nearly $50 \%$ of their estimated potential Western market capitalization. ${ }^{51}$ The critical difference between these firms appeared to be the quality of their corporate governance practices: firms with good governance rankings traded as high as $48 \%$ of their estimated Western market capitalization, while firms with low rankings traded at under $1 \%$.

As Professor Black notes, similar research on corporate governance practices in the United States or other Western nations has not yielded similarly dramatic results. ${ }^{\breve{j}^{2}}$ Thus, the key factor underlying the strength of the correlation between governance practices and market value in his study may be the weakness of the underlying Russian law and the entire Russian legal system. If legal rules are too weak or underenforced to provide protection, alternative sources of protection become correspondingly more important.

For precisely this reason, it is necessary to examine more closely

49 See Black, supra note 11, at 2148 ("In Russia, firm-level variation in governance behavior appears to have a huge effect on market value. It is the dominant source of interfirm variation in the value ratio of actual market capitalization to potential Western market capitalization.").

${ }^{30}$ Id. at 2140 tbl.2.

${ }^{51}$ Only one firm, Vimpelcom, traded at this approximate level (actually $48 \%$ ), and it was listed on the New York Stock Exchange. Id. The next highest firms traded at $18 \%$ and $16 \%$ of their estimated potential Western capitalization, while the lowest ranking traded at $0.01 \%$ and $0.02 \%$. Id.

${ }^{52}$ Id. 2148 ("In developed countries, firm-level variation in corporate governance practices has a minor effect on market value."). 
the factors that comprised the corporate governance rankings in his study. Basically, they fall into two general categories: (1) reputational factors, and (2) bonding efforts that give rise to enforceable rights. For example, a Russian company's past reputation and the attitude of its management toward shareholders may signal a sincere intent to comply with social norms that generally prevail in the West, but they confer no enforceable rights. Conversely, a preemptive rights charter provision, a low ceiling on authorized shares, or the deliberate creation of a blocking position that permits minority shareholders to veto proposed charter amendments do create enforceable rights. They are efforts at bonding because they tie management's hands-at least to the extent that Russian courts will enforce the corporate contract as it was written. Such contractual rights (even if they only establish procedures) are quite different from nonlegally enforceable norms (or "NLERS"). Thus, while Professor Black's data tends to confirm that "corporate governance matters," it is far more equivocal evidence as to whether "norms matter." That is, to the extent we define norms as conventions and practices that may be expected but are not legally enforceable, some of the factors in the corporate governance rankings that he uses do give rise to enforceable protections (while others are only reputational in character). Hence, it is indeterminate whether his data show the market responding to unenforceable signals of an intent to comply with Western norms of corporate governance or to more objective and enforceable measures that effectively create contractual rights.

This same ambiguity also underlies earlier studies. I have previously suggested that the cross-listing by non-U.S. firms on the New York Stock Exchange ("NYSE") also represents a form of

Professor Black's research uses some eight elements to determine "corporate governance rish." IH. at 2138 tbl.1. Some of these factors on Table 1 depend upon the company's prior reputation. For example, the first factor, "Disclosure \& Transparency," looks in part to the firm's "poor reputation for openness" and "poor shareholder meeting notice." Id. Obviously, whatever the company's past reputation, its hehavior can change in the future. Other elements depend, however, upon enforceable rights. For example, the second factor, "Dilution Through Share Inuance," looks to such factors as "No portfolio investor blocking stake" and "No preemptive rights in charter." Id. These are objective factors that involve the company deliberately restricting its management's discretion in order to assure investors that they will not be exploited. Such self-imposed restrictions are examples of "bonding." Sor Michael C. Jensen \& William H. Meckling, Theory of the Firm: Managerial Behavion, Igrocy Costs and Ohoncrship Structure, 3 J. FIN. ECON. 305 (1976). Because the majority of the elements on the rating score sheet used to determine the rankings employed in Professor Black's study are reputational and do not involve enforceable rights, I have vome shepticism that these rankings will have continuing or constant predictive value. 
bonding, as it assures investors of enhanced disclosure and potentially subjects them to litigation in U.S. courts. ${ }^{54}$ While it has long been known that such a cross-listing on the NYSE by a foreign firm elicits an increase in its stock price, recent research has found that firms incorporated in jurisdictions having "weak" corporate laws are more likely to cross-list than firms incorporated in jurisdictions with "strong" corporate laws. ${ }^{55}$ Subsequent to cross-listing in the United States, foreign firms are also more likely to conduct an equity offering in their own country, thus suggesting that a U.S. cross-listing gives meaningful assurances to investors in the firm's home country.

But what exactly is the market responding to when the stock price of a foreign firm that cross-lists in the United States increases? Is it the enforcable promise of better and fuller disclosure (based on the obligation to satisfy U.S. generally accepted accounting principles)? Is it the potential threat of Rule $10 \mathrm{~b}-5$ liability if the issuer makes false statements? Or is it simply the signal that the firm is seeking to improve its corporate governance? Alternatively, the price increase might not be the result of bonding at all, but could be a response to the change in supply and demand once the firm taps into the much larger U.S. capital market.

These ambiguities prevent bottom-line conclusions at this point. Clearly, self-help efforts to signal intended compliance with norms matter when the corporation takes action that truly binds the hands or limits the discretion of those who might violate those norms. For example, inclusion in the corporate charter of a provision establishing preemptive rights should logically have as much real world impact as the existence of a legal rule that mandates preemptive rights. Whether mere precatory statements by the corporation not accompanied by measures giving rise to enforceable rights also impact on a firm's valuation is more open to question because the existing research has not yet isolated the specific elements in corporate governance policies that affect market value.

Even if precatory corporate signals to the market (that is, those not accompanied by actions that limit the discretion of the selfinterested actor) do affect market value (as is certainly possible), it

${ }^{54}$ Coffee, supra note 20 , at 674 .

55 See William A. Reese, Jr. \& Michael S. Weisbach, Protection of Minority Shareholder Interests, Cross-Listings in the United States, and Subsequent Equity Offerings 3 (Jan. 29, 2000), http://papers.ssrn.com/sol3/papers.cfm?cfid=222015\& cftoken= $31298607 \&$ abstract_id=194670 ("The desire to protect shareholder rights appears to be one of a number of reasons why non-U.S. firms cross-list in the United States."). 
should not be assumed that the market has necessarily found its equilibrium position. Such precatory signals are relatively costless, and if they do affect market value, it can be assumed that many firms will eventually send them. At this point, a Gresham's Law of promises may take hold, as "bad" signals will proliferate and drive out the "good." Eventually, as in the classic "lemons market," all such signals will be discounted equivalently unless and until investors find ways to discriminate between the "honest" signals and the "false" signals.

For these reasons, I am somewhat less optimistic than Professor Black may be that corporate governance rankings, particularly to the extent they are based on precatory or nonbinding commitments, will continue to correlate closely with stock market valuations in transitional markets. Still, an enormous role exists, particularly in transitional economies, for creative legal engineering to make such signals credible. Those who are successful create value-precisely because the formal law is weak.

\section{CONCLUSION}

Norms do matter, but exactly when and to what extent remain more problematic issues. The magnitude of the variations in the private benefits of control across countries cannot be satisfactorily explained simply in terms of differences in substantive corporate law or associated enforcement systems. Law compliance also varies across countries, although not in a manner that systematically parallels the variations in the private benefits of control. Still, to varying degrees, social forces that are independent of any legal sanction constrain managers and controlling shareholders. What explains the striking variations among countries remains, however, largely unexplained.

One tentative generalization, however, may be advanced: norms may matter most when law is the weakest. When formal law does not adequately protect shareholders, the strength of social norms becomes more important, because they could provide a functional substitute for law. Conversely, when legal rights and remedies adequately protect investors, there is less need for corporations to signal their intentions to observe standards that are already legally

"Set George A. Akerlof, The Market for "Lemons": Quality Uncertainty and the Market Mrchanism, 84 Q.J. ECON. 488, 489-90 (1970) (noting that when buyers in a market (including investors in the securities market) cannot distinguish "good" from "bad" merchants, they will discount all more or less equally). To escape this dilemma, signals must be credible-particularly once they become common. 
mandated or to develop creative means by which to bond those promises through self-help corporate governance measures. This may explain why corporate governance measures have seldom been found to affect the corporation's stock price in the United States, but apparently do have such an impact in Russia. ${ }^{57}$

When law is weak and social norms about shareholders' rights are also underdeveloped (as appears to be the case today in Russia and possibly in French civil law countries), then credible signals about the corporation's intentions (and those of its controlling shareholders) become critical. The open question is when such a signal will be credible. Obviously, the more it is made enforceable, the more it becomes a functional substitute for legal rules. Even naked promises unaccompanied by corporate actions may sometimes work if the corporation has previously developed a reputational capital surplus that it can in effect pledge. ${ }^{5 s}$ In these respects, both corporate practice and the task of corporate valuation may be more complex and challenging in transitional countries than in the common law world, where law and norms today largely coincide.

More generally, to the extent that trust is viewed as the social cement that holds the organization together, ${ }^{59}$ or that behavioral forces independent of the market and legal sanctions are seen as shaping cooperation within the firm, then the private benefits of control are likely to be determined by the strength of the normative consensus within the broader society within which the corporation functions. Trust is a learned behavior, not an innate one; thus, what the corporate participants learn in the broader environment necessarily carries over to their behavior within the firm.

This centrality of norms has potentially destabilizing implications for much contemporary corporate law scholarship. An entire genre of corporate scholarship has focused on the interjurisdictional competition in the market for corporate charters as allegedly the principal force that has sharpened and maintained the efficiency of

${ }^{57}$ See Black, supra note 11, at 2148 ("In developed countries, firm-level variation in corporate governance practices has a minor effect on market value.").

${ }_{58}$ This concept of pledging a firm's reputational capital has long been used to explain why reputations are particularly important among financial intermediaries, and especially underwriters. See Ronald J. Gilson \& Reinier H. Kraakman. The Mechanisms of Market Efficiency, 70 VA. L. REV. 549, 619 (1984) (“[T]he seller's investment in reputation demonstrates that it is not in his interest to misrepresent the accuracy of its information; and the buyer can rely upon that signal in lieu of engaging in costly verification itself.").

${ }^{59}$ This is the essential thesis advanced by Blair \& Stout, supra note 45. 
the American business corporation. ${ }^{60}$ Yet, if corporate behavior is as much or more driven by norms as legal rules, the importance of free competition in a market for legal rules would seem diminished or at least more open to question. Put differently, would law-abiding Scandinavian business managers really behave differently if their business were incorporated in Switzerland, Austria, or Italy? Arguably, the legal rules to which they were subject might change, but the normative frame of reference of the firm's managers would not. Alternatively, would more predatory businessmen from a French civil law jurisdiction exploit the latitude that Delaware corporate law gives them in the expectation that Delaware-chartered corporations will be governed according to U.S. corporate governance standards? To raise these questions is not to answer them. Rather, the point here is that while competition in the market for charters may allow the firm's founders to choose its formal governance structure, this choice among available sets of legal rules may be less important than corporate law scholars have assumed if managers operate within very variable normative boundaries determined by social forces and reputational sanctions.

The more one emphasizes the role of norms, or the more the empirical evidence demonstrates their impact, the less the corporation looks exclusively like a purely private contractual mechanism or a simple "nexus of contracts."

"wt For the fullest defense of the desirability of an open market for corporate charters, see RoBerta ROMANO, THE GENIUS OF AMERICAN CORPORATE LAW (1993). For representative alternative views, see Ehud Kamar, A Regulatory Competition Theory of Indetrminacy in Corporate Law, 98 CoLUM. L. REV. 1908 (1998); Jonathan R. Macey \& Geoffrey P. Miller, Toward an Interest-Group Theory of Delaware Corporate Law, 65 TEXAS L. REV. 469 (1987). This debate is not limited to the United States, but applies to Europe as well. See David Charny, Competition Among Jurisdictions in Formulating Conporate Law Rulks: An American Perspective on the "Race to the Bottom" in the European Communities, 32 HARV. INT'L L.J. 423 (1991). 
* $\quad * \quad * \quad * \quad * \quad *$ 